\title{
PROSPEK PENGEMBANGAN KOMODITI JAGUNG MELALUI PENDEKATAN AGRIBISNIS DI KECAMATAN KULO, KABUPATEN SIDENRENG RAPPANG
}

\author{
Muhammad Natsir ${ }^{1)}$ dan Rikawanto Eko Mulyawan ${ }^{2)}$ \\ ${ }^{1)}$ Badan Ketahanan Pangan, Kabupaten Sidenreng Rappang \\ ${ }^{2)}$ PS. Agribisnis, Fak. Pertanian, Universitas Tribhuwana Tunggadewi
}

\begin{abstract}
This study was aimed to elucidate trend of harvesting area and maize yield, and policies supporting maize delopment through agribusiness approache in Kulo District of Sidenreng Rappang Regency. This study was conducted at Kulo District which is are known as a maize development area in Sidenreng Rappang Samples selected for this study comprised 50 farmers of 310 maize farmers at Kulo District. The collected data were then subjected to Qualitative-descriptive, trend and SWOT analyses. Results of this study showed that: (1) trends of harvest area and production of maize were linear and tended to increase every year, and (2) the policy strategies adopted for maize development using agribusiness approach were (a) production aspect, (b) institutional aspect, (c) financial aspects, (d).Harvest technology aspect, and (f) human resource aspects.
\end{abstract}

Key words:

\section{Pendahuluan}

Pertanian merupakan sektor yang sangat penting dalam perekonomian nasional. Oleh karena itu, pembangunan ekonomi nasional abad ke XXI, masih tetap berbasis perkembangan ekonomi, maka kegiatan jasa-jasa dan bisnis yang berbasis pertanian juga akan semakin meningkat, yaitu kegiatan agribisnis (termasuk agroindustri) akan menjadi salah satu kegiatan keunggulan pembangunan ekonomi nasional dalam berbagai aspek yang luas (Saragih, 2001).

Salah satu komoditi tanaman pangan yang dapat mengambil peran dalam pembangunan sektor pertanian adalah komoditi jagung. Di Indonesia, jagung merupakan bahan pangan penting karena merupakan sumber karbohidrat ke dua setelah beras. Di samping itu, jagung pun digunakan sebagian bahan pakan ternak dan bahan baku industri.

Perkembangan pertanaman jagung di Sulawesi Selatan masih terkonsentrasi pada daerah-daerah Jeneponto, Bantaeng, Sinjai, Takalar, dan Bulukumba. Potensi lahan yang dimiliki propinsi ini adalah 446.500 ha, yang penanamannya sebagian besar pada periode bulan Nopember - Maret seluas \pm 214.500 ha dan bulan Juli- September seluas \pm 126.500 ha. Kabupaten 
Sidenreng Rappang merupakan salah satu kabupaten sentra komoditi jagung. Rata-rata produksi jagung periode tahun 2002 - 2006 mencapai 7.070,00 ton, sementara kebutuhan lokal pakan jagung mencapai 66 ton/hari atau 24.090 ton/tahun. Hal ini berarti produksi jagung hanya mampu memenuhi $29,25 \%$ dari kebutuhan pakan ternak khususnya jagung pada setiap tahunnya.

Dalam rangka mendorong perkembangan komoditi agribisnis dengan melihat potensi sumberdaya alam khususnya lahan pertanian, Pemerintah Kabupaten Sidenreng Rappang menetapkan Visi yakni "Mewujudkan Sidenreng Rappang Menjadi Pusat Pengembangan Agribisnis yang Mandiri, Berbudaya dan Religius".

Menurut Musa (2002), program pengembangan jagung adalah upaya yang perlu mendapat prioritas mengingat komoditas tersebut peranannya cukup strategis di dalam menunjang sistem ketahanan pangan. Untuk itu peningkatan produksi dan produktivitas perlu dipacu melalui pendekatan: 1) Intensifikasi Khusus adalah suatu pola intensifikasi yang dilakukan oleh kelompok tani berdasarkan hamparan usahatani dengan menerapkan paket teknologi yang dianjurkan, 2) Perluasan areal tanam yang kegiatannya menitik beratkan kepada peningkatan indeks pertanaman

Komoditi jagung merupakan salah satu komoditi yang patut mendapatkan perhatian oleh semua pihak, dimana potensi seperti dukungan luas lahan, sifat fisik dan kimia tanah, agroklimat, tenaga kerja serta pemasaran produksi sangat memungkinkan berkembangnya komoditi ini (Rukmana, 1997).. Adaptasi dan tingkat toleransinya sangat tinggi terhadap lingkungan sehingga dapat tumbuh pada berbagai macam tanah dan bahkan kondisi tanah yang agak kering pun jagung masih dapat tumbuh dan berproduksi. Tujuan penelitian ini adalah untuk mengetahui prospek pengembangan komoditi jagung di Kecamatan Kulo, Kabupaten Sidenreng Rappang.

\section{Metode Penelitian}

Penelitian ini dilaksanakan di Kecamatan Kulo Kabupaten Sidenreng Rappang. Kecamatan Kulo merupakan daerah pengembangan komoditi jagung di Kabupaten Sidenreng Rappang. Penelitian ini berlangsung pada April sampai Juni 2007.

Populasi dalam penelitian ini adalah petani yang melaksanakan usahatani jagung yang berada dalam Wilayah Kecamatan Kulo yang terdiri atas 310 petani jagung terpilih secara acak 50 sampel/responden. Jenis data yang digunakan dalam penelitian ini adalah data primer dan data sekunder.

Analisis data meliputi (a) analisis deskriptif Kualitatif untuk menjelaskan sejauh mana penerapan sistem-sistem agribisnis jagung di Kecamatan Kulo, Kabupaten Sidenreng Rappang, dan (b) analisis Trend untuk melihat tingkat kecenderungan luas panen dan produksi jagung dengan mengambil data 5 (lima) tahun terakhir. Untuk memudahkan perhitungan dalam mencari persamaan Trend digunakan tahun kode $(\mathrm{X})$ sebagai pengganti tahun sesungguhnya. Bentuk umum persamaan analisis Trend linear yang dikemukakan Mulyono (1998) secara berturut-turut sebagai berikut:

$Y t=a+b x$
$a=\frac{\sum y}{n}$ dan $b=\frac{\sum x y}{\sum x}$ 
Dimana:

$$
\begin{aligned}
\mathrm{Yt}= & \text { Nilai Trend untuk produksi dan } \\
& \text { luas panen (periode) tertentu. } \\
\mathrm{a}= & \text { Nilai Yt jika } \mathrm{x}=0 \text { pada nilai } \\
& \text { Yt pada periode t. } \\
\mathrm{b}= & \begin{array}{l}
\text { Kemiringan garis Trend artinya } \\
\text { besarnya perubahan Yt jika } \\
\text { terjadi perubahan satu besaran }
\end{array} \\
& \text { periode waktu. } \\
\mathrm{x}= & \text { Kode periode waktu } \\
\mathrm{n}= & \text { Banyaknya pasangan data }
\end{aligned}
$$

Penetapan strategi kebijakan tentang prospek pengembangan jagung melalui pendekatan agribisnis di Kecamatan Kulo, Kabupaten Sidenreng Rappang pada masa yang akan datang dilakukan dengan analisis SWOT (Rangkuti, 2002). Penggabungan SWOT menjadi suatu matrik dan kemudian diidentifikasikan semua aspek dalam SWOT disusun menurut metode Wahyudi (2006) yang menggunakan sistem kuadran. Dari kuadran tempat bertemunya SWOT tersebut kemudian dibuat strategi yang sesuai dengan aspek-aspek SWOT. Strategi-strategi dimaksud sebagai berikut:

a. Strategi S - O (maksi-maksi) yaitu memaksimalkan potensi kekuatan untuk meraih peluang semaksimal mungkin atau menggunakan kekuatan untuk menangkap kesempatan.

b. Strategi S - T (maksi-mini) yaitu memaksimalkan potensi/kekuatan untuk mengurangi seminimal mungkin ancaman yang ada atau menggunakan kekuatan untuk menghindarkan ancaman yang ada.

c. Strategi W - O (mini-maksi) yaitu meminimalkan kelemahan untuk meraih peluang semaksimal mungkin atau mengatasi kelemahan dengan mengambil kesempatan. d. Strategi W - T (mini-mini) yaitu meminimalkan kelemahan untuk meminimalkan ancaman yang ada atau menghindarkan ancaman.

\section{Hasil dan Pembahasan}

\section{Karakteristik Responden}

Tingkat umur petani responden $31-40$ tahun berjumlah 21 atau $42 \%$ merupakan jumlah tertinggi menyusul tingkat umur $51-60$ tahun berjumlah 10 atau $20 \%$, dan yang paling kecil jumlahnya adalah tingkat umur $61-70$ tahun berjumlah 83 atau $16 \%$. Oleh karena usia produktif yang mendominasi responden, sehingga dapat dijadikan sebagai kekuatan dalam pengembangan komoditi jagung di masa-masa datang. Menurut Soekartawi (1993), yang termasuk usia produktif yaitu umur 15 tahun sampai dengan 60 tahun.

Semua responden pernah mengikuti pendidikan formal, hal ini merupakan salah satu kekuatan dalam pengembangan komoditi jagung. Sebagian besar tingkat pendidikan responden adalah SMP yaitu 20 orang atau $40 \%$, selanjutnya yang memiliki tingkat pendidikan SMA/SMEA yaitu 16 orang atau $32 \%$ dan Tingkat pendidikan SD/SR 13 orang atau 26\%, dan yang paling kecil jumlahnya adalah responden yang tingkat pendidikannya Sarjana yaitu 1 orang atau $2 \%$.

Pengalaman petani jagung masih relatif rendah. Pengalaman 1 sampai 3 tahun memperlihatkan angka tertinggi yaitu 30 orang atau $60 \%$ menyusul pengalaman 4 sampai 6 tahun yaitu 16 orang atau $32 \%$, serta pengalaman 7 sampai 9 tahun hanya 4 orang atau $8 \%$. Sungguhpun demikian, dengan pengalaman yang relatif rendah petani responden pada umumnya memahami teknik budidaya komoditi jagung. 
Pengalaman berusahatani ini cukup memadai dan dapat dijadikan sebagai penunjang dalam pengembangan komoditi jagung di Kecamatan Kulo, Kabupaten Sidenreng Rappang.

Jumlah anggota petani yang terbanyak adalah $3-4$ orang adalah 28 orang atau $56 \%$ dan yang terendah adalah jumlah tanggungan $7-8$ orang adalah 2 orang atau $4 \%$, sementara jumlah tanggungan 1 sampai 2 orang adalah 15 orang atau 30\%. Jumlah tanggungan keluarga pada umumnya dalam usia produktif, sehingga dapat dijadikan sumber tenaga kerja dalam usahatani jagung. Dengan demikian kebutuhan akan tenaga kerja dapat dipenuhi dalam keluarga, sehingga secara tidak langsung mengurangi pengeluaran tunai dalam proses usahatani.

Luas lahan garapan responden yang paling besar adalah luasan 0,3 - 0,7 ha yaitu 30 orang atau $60 \%$ menyusul luas lahan garapan $0,8-1,2$ ha yaitu 16 orang atau $32 \%$, sementara luasan $1,3-$ 2,2 ha hanya 4 orang atau $8 \%$. Sungguh pun demikian luas lahan garapan tersebut di atas antara $0,3-2,2$ ha telah memberikan pendapatan buat keluarganya.

\section{Produksi dan Luas Panen Jagung}

Untuk memperoleh hasil tingkat kecenderungan produksi dan luas panen jagung di Kabupaten Sidenreng Rappang maka dilakukan pendekatan analisis yaitu analisis Trend. Analisis ini diuji dengan mengumpulkan data 5 (lima) tahun terakhir mengenai luas panen dan produksi jagung yaitu mulai tahun 2002 sampai pada tahun 2006 (Tabel 1). Berdasarkan hasil analisis Trend mengenai luas panen dan produksi jagung di Kecamatan Kulo cenderung mengalami peningkatan.
Data yang disajikan dalam Tabel 1 menunjukkan bahwa perkembangan luas panen, produksi dari tahun 20022006 cenderung berfluktuatif. Produksi tertinggi dicapai pada tahun 2005 yaitu $1.194,09$ ton, sementara luas panen tertinggi dicapai juga pada tahun 2005 yaitu 318 ha.

Tabel 1.Jumlah Luas Penen, Produksi serta Produkstivitas Periode Tahun 2000 - 2004 Kecamatan Kulo.

\begin{tabular}{cccc}
\hline Tahun & $\begin{array}{c}\text { Luas } \\
\text { Panen } \\
\text { (ha) }\end{array}$ & $\begin{array}{c}\text { Produksi } \\
\text { (Ton) }\end{array}$ & $\begin{array}{c}\text { Produktivitas } \\
\text { (Ton/ha) }\end{array}$ \\
\hline 2002 & 61 & 159,82 & 26,20 \\
2003 & 218 & 621,30 & 28,50 \\
2004 & 124 & 447,64 & 36,10 \\
2005 & 318 & $1.194,09$ & 37,55 \\
2006 & 97 & 364,24 & 37,55 \\
\hline Jumlah & 848 & $2.787,09$ & 33,81 \\
\hline \multicolumn{5}{l}{ Sumber:Dinas Pertanian Tanaman Pangan } \\
dan Perkebunan, Kabupaten Sidenreng \\
Rappang tahun 2007.
\end{tabular}

Produktivitas cenderung mengalami peningkatan dari 26,20 ton/ha pada tahun 2002 dan pada tahun 2006 mencapai 37,55 ton/ha. Hasil perhitungan Trend luas panen dari tahun 2002 - 2011 (Gambar 1) menunjukkan bahwa hasil analisis perhitungan trend luas panen di Kecamatan Kulo dari tahun ke tahun cenderung mengalami peningkatan atau linear. Trend perkembangannya pada setiap tahunnya yaitu 17,2 ha yang dimulai pada tahun 2002 yaitu $112 \mathrm{Ha}$. Trend luas panen pada tahun 2005 dan 2006 masingmasing 163,60 dan 180,80 ha. Pada tahun 2011 trend perkembangan luas panen mencapai 284 ha.

Trend perkembangan produksi yang disajikan pada Gambar 2 menunjukkan bahwa trend produksi jagung di Kecamatan Kulo terjadi peningkatan 
dari tahun ke tahun yaitu 98,1 ton. Kenaikan ini terhitung mulai pada tahun 2002 dengan trend produksi 361,2 ton sampai pada tahun 2011. Trend produksi pada tahun 2011 mencapai 1.244,10 ton.

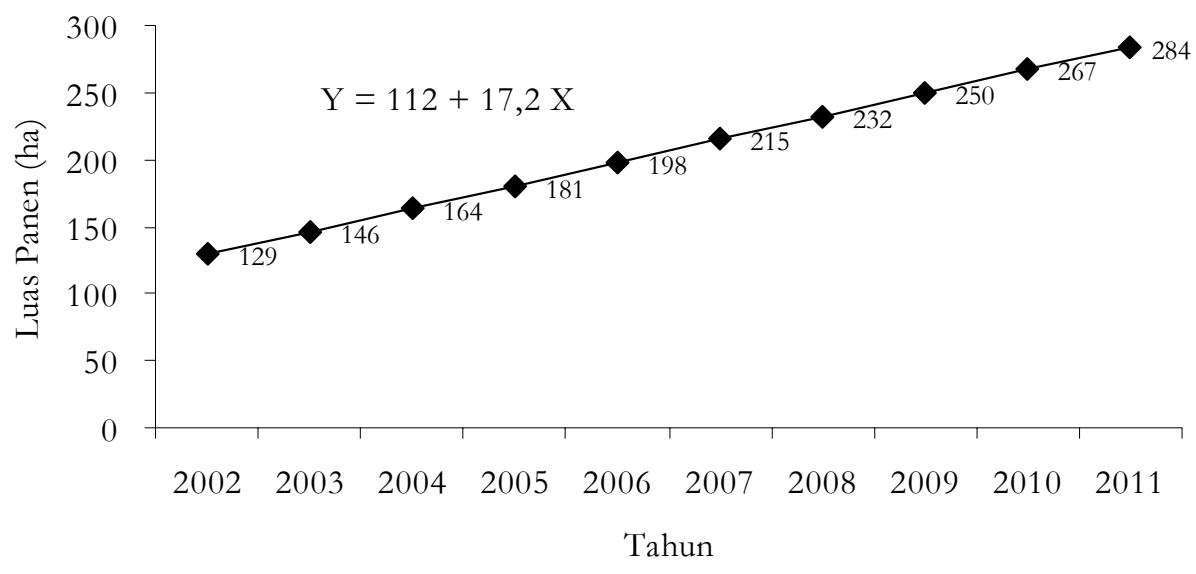

Gambar 1. Trend Luas panen Jagung di Kecamatan Kulo, Kabupaten Sidenreng Rappang

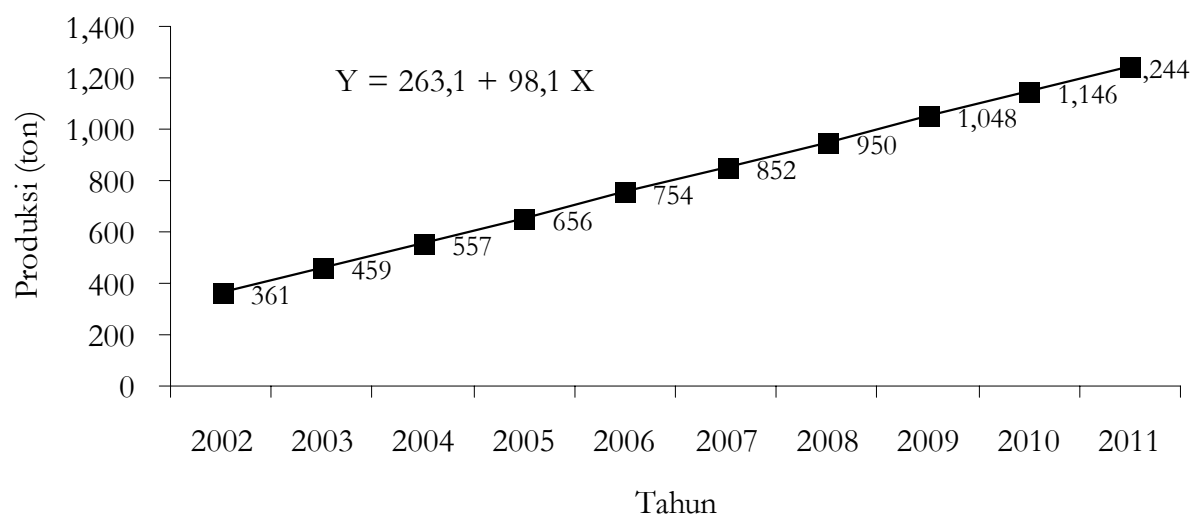

Gambar 2. Trend Produksi Jagung di Kecamatan Kulo, Kabupaten Sidenreng Rappang

\section{Strategi Kebijakan Pengembangan Jagung}

Guna memperoleh strategi kebijakan pengembangan jagung dengan pendekatan agribisnis maka analisis yang digunakan adalah analisis SWOT (Strenghts, Weaknesses, Opportunities, dan Threats). Model analisis untuk dapat menetapkan strategi yaitu membandingkan faktor eksternal berupa peluang dan ancaman dengan faktor internal berupa kekuatan dan kelemahan. Kelemahan utama dalam pengembangan komoditi jagung, yaitu (1) Belum diterapkan sepenuhnya teknologi budidaya yang dianjurkan (2) 
Masih kemampuan ekonomi petani masih lemah. Faktor kekuatan dalam pengembangan komoditi jagung adalah (1) Tersedianya potensi areal pengembangan jagung, (2) Tingginya motivasi/animo petani terhadap pengembangan komoditi jagung.

Berdasarkan hal tersebut di atas, maka perlu dilakukan perbaikan dan peningkatan SDM petani agar inovasiinovasi yang berkaitan dengan budidaya jagung dapat dilakukan yang didukung dengan keberpihakan lembaga penunjang khususnya lembaga keuangan untuk memfasilitasi mereka dalam hal penguatan modal. Hal ini penting dalam menunjang kegiatan usahataninya yang diharapkan dapat dikelola sesuai anjuran sehingga implikasinya terhadap kuantitas dan kualitas produksi dapat dicapai. Demikian pula halnya dengan ketersediaan potensi areal pengembangan harus betul-betul dioptimalkan pemanfaatannya oleh karena dukungan masyarakat petani yang memiliki motivasi dan animo yang cukup tinggi terhdapa pengembangan jagung. Pada masa yang akan datang dengan memaksimalkan kekuatan dan meminimalkan kelemahan pengembangan jagung di Kabupaten Sidenreng Rappang akan lebih baik.

Faktor strategi eksternal peluang untuk pengembangan komoditi jagung lebih besar daripada ancaman yang akan menghambat pengembangannya. Ancaman yang paling besar dalam pengembangan komoditi kakao fermentasi yaitu: (1) Harga komoditi jagung berfluktuatif, (2) Berkembang pesatnya pertanaman jagung dari daerah luar. Peluang besar dalam pengembangan jagung adalah (1) Permintaan pasar cukup besar, (2) Dukungan Agroklimat, Geografi, danj Topografi.
Matriks strategi disusun menurut metode yang dikembangkan oleh Wahyudi (1996) sebagai berikut

\section{Strategi SO}

Dengan melihat faktor-faktor kekuatan terbesar dalam pengambangan jagung seperti tresdianya potensi areal pengambangan yang cukup, tingginya motivasi/animo petani, tersedianya dukungan tenaga kerja, usahatani jagung dapat memberikan keuntungan serta tersedianya sumberdaya dan tenaga aparat penyuluh yang cukup, maka faktor kekuatan ini ditunjang oleh faktor peluang sehingga menjadi pendorong yang kuat bagi pengambangan komoditi jagung. Untuk strategi yang dipilih adalah 1) Mengoptimalkan pemanfaatan lahan serta meningkatkan kinerja aparat penyuluh dalam pembinaan pengembangan usahatani jagung, 2) Memfasilitasi terbentuknya Sub Terminal Agribisnis (STA) pada sentra pengembangan, 3) Membuka hubungan kemitraan dengan para pelaku atau pengusaha yang bergerak di bidang agribisnis.

\section{Strategi $W O$}

Melihat kelemahan-kelemahan berupa: belum optimalnya dukungan infrastruktur, kemampuan ekonomi petani masih lemah, masih terbatasnya tenaga terampil/SDM yang menguasai teknologi, belum diterapkan teknik budidaya jagung sesuai anjuran, maka perlu strategi mengatasinya dengan memanfaatkan peluang yang ada seperti: pemasaran pasar cukup besar, dukungan agroklimat, geografi, dan topografi, dukungan pemerintah daerah, propinsi, dan pusat yang cukup serta berkembangnya industri yang menggunakan bahan baku jagung, banyaknya produk diversifikasi jagung. 
Tabel 2. Alternatif Strategi Pengembangan Komoditi Jagung.

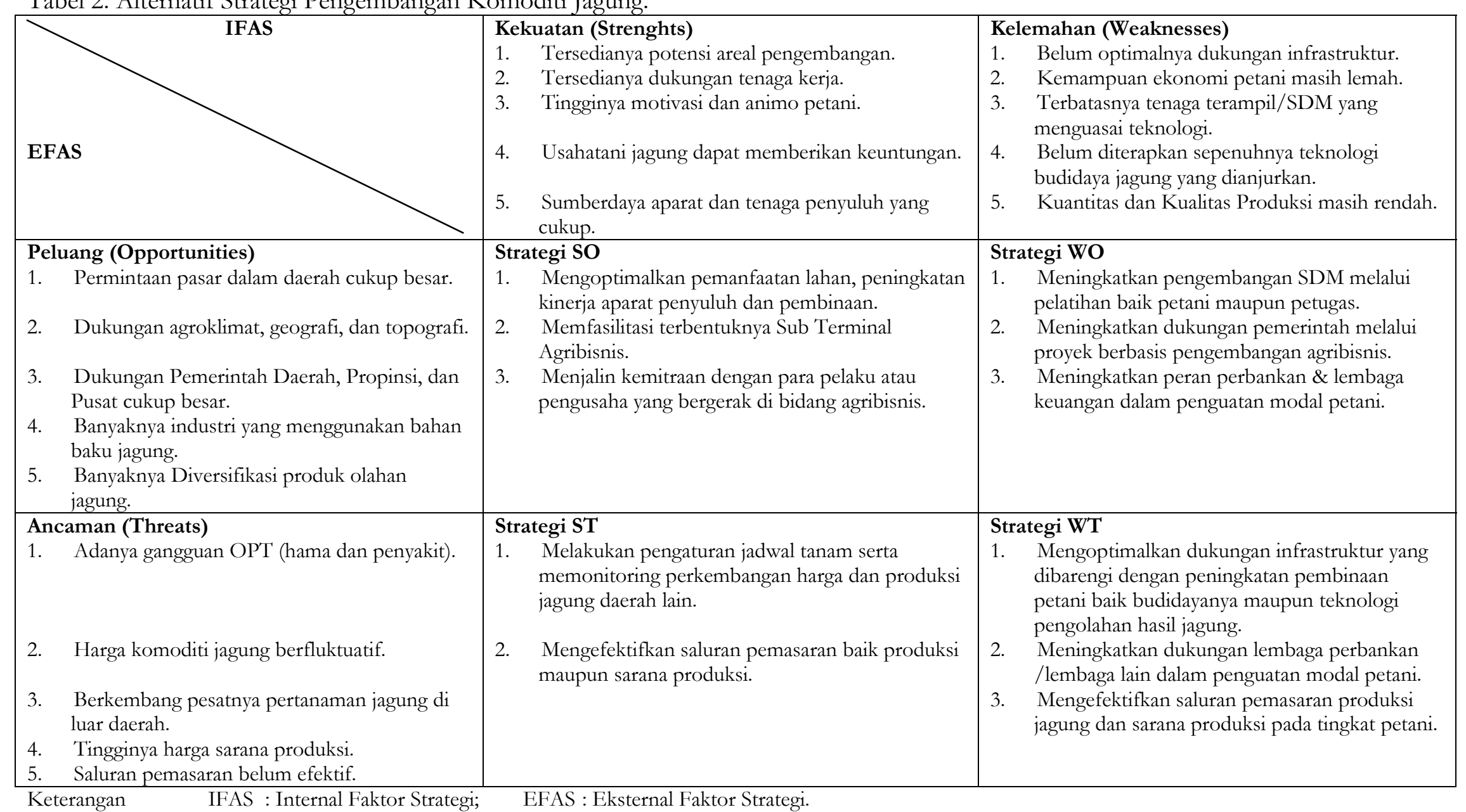


Untuk itu strategi yang dipilih adalah 1) Meningkatkan pengembangan SDM melalui pelatihan-pelatihan baik petani maupun petugas, 2) Meningkatkan dukungan pemerintah melalui kegiatankegiatan proyek perbankan/serta lembaga keuangan lainnya dalam penguatan modal petani.

\section{Strategi ST}

Melihat ancaman-ancaman berupa: adanya gangguan OPT (hama dan penyakit, harga komoditi jagung berfluktuatif, masih rendahnya kuantitas dan kualitas jagung, berkembang pesatnya pertanaman jagung dari luar daerah, serta saluran pemasaran belum efektif, maka dapat dilakukan strategi dengan memanfaatkan kekuatan seperti: tersedianya potensi areal pengembangan, tersedianya dukungan tenaga kerja, tingginya motivasi dan animo petani, usahatani jagung memberikan keuntungan serta sumberdaya tenaga parat penyuluh yang cukup. Strategi yang dipilih adalah: 1) Melakukan pengaturan jadwal tanam serta memonitoring perkembangan harga dan produksi jagung daerah lain, 2) Mengefektifkan saluran pemasaran baik produksi maupun sarana produksi.

\section{Strategi $W T$}

Melihat ancaman-ancaman berupa: adanya gangguan OPT (hama dan penyakit, harga komoditi jagung berfluktuatif, masih rendahnya kuantitas dan kualitas jagung, berkembang pesatnya pertanaman jagung dari luar daerah, serta saluran pemasaran belum efektif. Kelemahan-kelemahan seperti: belum optimalnya dukungan infrastruktur, kemampuan ekonomi petani masih lemah, masih terbatasnya tenaga terampil/SDM yang menguasai teknologi, belum diterapkan teknik bididaya jagung sesuai anjuran.
Dalam upya pengembangan komoditi jagung tersebut, maka strategi yang dapat dilakukan adalah: 1) Mengoptimalkan dukungan infrastruktur yang dibarengi dengan peningkatan pembinaan petani baik budidayanya maupun teknologi pengolahan hasil jagung, 2) Meningkatkan dukungan lembaga perbankan atau lembaga jasa lainnya dalam penguatan modal petani, 3) Mengefektifkan saluran pemasaran produksi jagung dan sarana produksi pada tingkat petani.

\section{Kesimpulan}

Tingkat kecenderungan (trend) perkembangan luas panen dan produksi komoditi jagung di Kecamatan Kulo, Kabupaten Sidenreng Rappang adalah linier, yang menunjukkan komoditi jagung memiliki prospek yang baik untuk dikembangkan, akan tetapi trend perkembangannya masih relatif sedikit dibandingkan dengan tingkat kebutuhan jagung dalam daerah.

Strategi kebijakan pengambangan jagung dengan pendekatan agribisnis adalah:

- Aspek Produksi yaitu: (1) mengoptimalkan pemanfaatan lahan serta meningkatkan kinerja aparat penyuluh dalam pembinaan pengembangan jagung, dab (2) melakukan pengaturan jadwal tanam serta memonitoring perkembangan harga dan produksi jagung daerah lain

- Aspek Kelembagaan yaitu: (1) memfasilitasi terbentuknya Sub Terminal Agribisnis (STA), dan (2) menjalin kemitraan dengan para pelaku atau pengusaha yang bergerak di bidang agribisnis,

- Aspek Sumberdaya Manusia yaitu: Menigkatkan pengembangan SDM 
melalui pelatihan baik petugas maupun petani,

- Aspek Pembiayaan yaitu: (1) meningkatkan dukungan pemerintah melalui kegiatan proyek yang berbasis pengembangan agribisnis, dan (2) meningkatkan peran perbankan serta lembaga keuangan lainnya dalam penguatan modal petani,

- Aspek Pengolahan Hasil yaitu mengoptimalkan dukungan infrastruktur yang dibarengi dengan peningkatan pembinaan petani terhadap teknologi pengolahan hasil jagung,

- Aspek Pemasaran yaitu: mengefektifkan saluran pemasaran baik produksi jagung maupun sarana produksi.

\section{Ucapan Terima Kasih}

Penulis mengucapkan terima kasih kepada Pimpinan dan Staf Dinas Pertanian dan Badan Ketahanan Pangan, Kabupaten Sidenreng Rappang atas bantuan pengumpulan data penelitian.

\section{Daftar Pustaka}

Mulyono, Sri, 1998. Statistika Untuk Ekonomi (Edisi Revisi), Fakultas Ekonomi Universitas Indonesia.

Musa, S., 2002. Pengembangan Model Intensifikasi jagung, Direktorat Jenderal Tanaman Pangan Departemen Pertanian, Jakarta.

Rangkuti, F,. 2002. Analisis SWOT, Teknik Membedah Kasus Bisnis. Gramedia Jakarta.

Rukmana, H. R., 1997. Usahatani Jagung, Kanisius, Yogyakarta.

Saragih, B,. 2001. Paradigma Baru Pembangunan Ekonomi Berbasis Pertanian. Loji Grafika Griya Sarana, Bogor.

Soekartawi, 1993. Prinsip Dasar Ekonomi Pertanian, Rajawali Press, Jakarta.

Wahyudi, A. S. 1996. Manajemen Strategis, Binarupa Aksara. Jakarta Barat. 
-Redaksi: Halaman ini sengaja dikosongkan- 